(International Journal of Agriculture and Wildlife Science)
http://dergipark.org.tr/ijaws

Araştırma Makalesi

\title{
Sulu ve Kuru Koşullarda Yetiştirilen Bazı Horoz ibiği Çeşitlerinin Tohum ve Samanında Yem Kalite Özelliklerinin Belirlenmesi
}

\author{
Bilal Keskin $^{1 *}$, Süleyman Temel ${ }^{1}$, Ramazan Tosun ${ }^{2}$, Selma Çakmakçı \\ ${ }^{1}$ Iğdır Üniversitesi Ziraat Fakültesi Tarla Bitkileri Bölümü, Iğdır \\ ${ }^{2}$ Iğdır Üniversitesi Ziraat Fakültesi Zootekni Bölümü, Iğdır
}

Geliş tarihi (Received): 08.09.2020 Kabul tarihi (Accepted): 16.10.2020

\begin{abstract}
Anahtar kelimeler:
Amaranthus, amaranth türleri, tohum ve saman kalitesi, sulu şartlar, kuru şartlar

*Sorumlu yazar

bilalkeskin66@yahoo.com

Özet. Araştırmada Amaranthus caudatus türüne ait Helios çeşidi, Amaranthus paniculatus x Amaranthus nutans türlerinin melezine ait Sterk çeşidi ve Amaranthus hybridus türüne ait Ultra çeşidi kullanılmıştır. Çeşitler kuru ve sulu şartlarda olmak üzere iki farklı ortamda yetiştirilmiştir. Araştırma bölünmüş parseller deneme desenine göre 3 rekrrürlü olarak 2017-2018 yıllarında 2 yıl süreyle yürütülmüştür. Araştırmada Amaranthus çeşitlerinin tohumda ham protein (tohum HP), samanta ham protein (saman HP), samanda nötr çözücülerde çözünemeyen lif (saman NDF), samanda asit çözücülerde çözünemeyen lif (saman ADF), samanda kuru madde sindirilebilirliği (saman KMS), samanda kuru madde tüketim oranı (saman KMT), samanda sindirilebilir enerji (saman $\mathrm{SE})$, samanda metabolik enerji (saman ME), ve samanda nispi yem değeri (saman NYD) belirlenmiştir. Yapılan analiz sonucu incelenen parametreler üzerine yılların (tohum HP, saman NDF ve saman NYD hariç), çeşitlerin ve kuru ve sulu koşulların (tohum HP hariç) etkisi önemli bulunmuştur. Buna göre saman ADF, HP ve KMT 2018 yılında, saman KMS, SE ve ME içeriği ise 2017 yılında daha yüksek bulunmuştur. Yetişme koşulları açısından, kuru şartlarda yetiştirilen Amarant çeşitlerinin samanlarının KMS, KMT, SE, ME ve NYD içerikleri sulu şartlarda yetiştirilmeye göre daha yüksek elde edilmiştir. Tohumda en yüksek ham protein Ultra çeşidinde elde edilirken, samanda en yüksek ham protein Helios çeşidinde elde edilmiştir. Sonuç olarak incelenen parametreler göz önüne alındığında, yüksek tohum ve saman kalitesine sahip Helios çeşidinin hayvan beslenmesinde tercih edilebileceği sonucuna varılmıştır.
\end{abstract}

\section{Determination of Feed Quality Characteristics of Seed and Straw of Some Amaranth Varieties Grown under Irrigation and Dry Conditions}

\section{Keywords:}

Amaranthus, amaranth species, seed and straw quality, irrigation condition, dry condition

\begin{abstract}
In the study, Helios variety of Amaranthus caudatus species, Sterk variety of the Amaranthus paniculatus $x$ Amaranthus nutans species and Ultra variety of the Amaranthus hybridus species were used. The varieties were grown in two different cultivation conditions (dry/irrigation). The research was carried out with 3 replications according to split plot experiment design for 2 years in 2017-2018. In the study, seed crude protein content (CP), straw crude protein content (CP), straw neutral detergent fiber (NDF) rate, straw acid detergent fiber (ADF) rate, straw dry matter digestibility $(D M D)$, straw dry matter intake (DMI) rate, straw digestible energy (DE), straw metabolic energy (ME), and straw relative feed value (RFV) of Amaranthus varieties were determined. As a result of the analysis, the effects of years (except seed HP, straw NDF and straw NYD), varieties and cultivation conditions (except seed HP) were found to be significant. Accordingly, straw ADF, HP and KMT content was higher in 2018, while straw KMS, SE and ME content was higher in 2017. DMD, DMI, DE, ME and RFV contents of straw of Amaranthus cultivars grown in dry conditions were higher than those grown in irrigation conditions. While the highest crude protein in the seed was obtained in Ultra variety, the highest crude protein in the straw was obtained in Helios variety. As a result, considering the examined parameters, it was concluded that Helios variety with high seed and straw quality can be preferred in animal nutrition.
\end{abstract}




\section{Giriş}

Amaranthus cinsine bağlı 60 kadar tür bulunmaktadır. Amaranthus cinsine bağlı birçok tür yabancı ot olarak bilinmesine rağmen, dünyanın birçok yerinde daneleri kanatlı ve monogastrik hayvanlarında, otu ise insan ve hayvan beslenmesinde yaygın olarak kullanılmaktadır (Grubbens and van Sloten, 1981; Sauer, 1976; Lee, 2011; Yarnia ve ark., 2011; Özaslan ve Kendal, 2014 Ergun ve ark., 2014;). Horoz ibiği bitkisi özellikle ABD, Rusya, Hindistan, Pakistan ve Çin'de üretimi ve ticareti yaygın olarak yapılmakta, Ülkemizde ise sadece yeşil kısımlarından sebze olarak faydalanılmaktadır (Robinson, 1986; Stahlknecht and Schulz-Schaeffer, 1993; Tan ve Temel, 2012; Ergun ve ark., 2014).

Amarant tohumlarındaki protein, yağ ve mineral içeriklerinin yüksek olması (Lehman 1989, Bressani, 1989; Uusikua ve ark., 2010; Caselato-Sousa ve Amaya-Farfàn, 2012; Alegbejo, 2013; Rastogi ve Shukla, 2013; Arendt and Zannini, 2013), tohumlarının gluten içermemesi ve bu nedenle un ve bisküvi endüstrisinde kullanılması (Lee, 2011; Rastogi and Shukla 2013; Hayıt ve Gül, 2017) amarant tohumlarının önemini artırmaktadır. Amarant bitkileri su streslerine karşı kök derinliklerini artırarak ortamın kurak şartlarına dayanıklılığını artıırlar (Johnson ve Henderson, 2002). Bu yönleriyle uzun süre kurak şartlara dayanabilirler. Ancak kuraklığın devam etmesi durumunda bitkinin generatif döneme ve hasat olgunluğuna geçmesi hızlanmaktadır (Ergun ve ark., 2014).

Amarant bitkisinin tohum ve yeşil aksamları genel olarak insan gıdası olarak tüketilmesine rağmen, bazı amarant türlerinin otu ve tohumu iyi kalitede hayvan yemi olarak kullanılmaktadır (Pospisil ve ark., 2008; Pospisil ve ark., 2009). Isıl işlem görmüş Amarant tohumları piliçlerin beslenme diyetlerine belirli oranlarda ilave edilmesi piliçlerin büyümesi üzerine ve yem kullanımı üzerine önemli etkilerinin olacağı bildirilmiştir (Connor ve ark., 1980; Laovoravit ve ark., 1986; Ravindran ve ark., 1996). Amarant tohumlarında nitrat, saponin ve fenolik bileşiklerinin olması ve herhangi bir ön işlem uygulanmadan yoğunlukla beslenmede kullanılması durumunda bazı toksik problemlerin de olabileceği rapor edilmiştir (Connor ve ark., 1980; Cheeke and Bronson, 1980; Betschart ve ark., 1981; Laovoravit ve ark., 1986). Amarant bitkilerinin tohum hasadından sonra kalan samanları hayvan beslemesinde kaba yem olarak kullanılabilmesine karşın, samanların besin içerikleri konusunda herhangi bir çalışma yapılmamış olması bir eksiklik olarak görülmüştür.

Bu araştırma hayvan yetiştiriciliğinin yapıldığı bölgelerde Amaranthus cinsine bağlı bazı tür ve çeşitlerinin sulu ve kuru şartlarda yetiştirilmesi durumunda tohum ve samanlarındaki yem değerlerinin belirlenmesi amacıyla yürütülmüştür.

\section{MATERYAL VE METOT}

Deneme Iğdır Üniversitesine ait Tarımsal Uygulama ve Araştırma Merkezi araştırma sahasında 2 (iki) yıl süreyle (2017 ve 2018) yürütülmüştür. Çizelge 1 incelendiğinde denemenin kurulduğu bölgenin uzun yıllar iklim değerlerine göre, yıllık toplam yağışı $266.3 \mathrm{~mm}$, ortalama sıcaklık $12.4^{\circ} \mathrm{C}$ ve nispi nem ise $\% 54.6$ olarak ölçülmüştür (MGM, 2019). Denemenin yürütüldüğü 2018 yılına göre, 2017 yılındaki toplam yağış, ortalama sıcaklık ve ortalama nispi nemin daha düşük olduğu görülmektedir (Çizelge 1).

Çizelge 1. Araştırmanın kurulduğu bölgenin bazı iklim değerleri (MGM, 2019).

Table 1. Some climatic values of the region where the research was established (MGM, 2019).

\begin{tabular}{lccc}
\hline & $\mathbf{2 0 1 7}$ yılı & $\mathbf{2 0 1 8}$ yılı & (1978-2017) yılları \\
\hline Ortalama Sıcaklık ( $\left.{ }^{\circ} \mathbf{C}\right)$ & 12.4 & 15.1 & 12.4 \\
Toplam Yağıș (mm) & 220.8 & 280.0 & 266.3 \\
Ortalama Nispi Nem (\%) & 58.4 & 60.0 & 54.6 \\
\hline
\end{tabular}

Iğdır Üniversitesi laboratuvarlarında yapılan analizlere göre, deneme alanına ait toprakların organik madde içeriği düşük, kireç içeriği yüksek, az tuzlu ve orta alkali olduğu belirlenmiştir (Çizelge 2).

Çizelge 2. Araştırmanın yürütüldüğü topraklara ait bazı özellikler.

Table 2. Some characteristics of the soils where the research was conducted.

\begin{tabular}{llllllll}
\hline $\mathbf{p H}$ & Kireç \% & EC $\left(\mathbf{M s ~ ~ c m ^ { - 1 } )}\right.$ & Organik Madde \% & $\mathbf{P}(\mathbf{p p m})$ & $\mathbf{K}(\mathbf{p p m})$ & $\mathbf{C a}(\mathbf{p p m})$ & $\mathbf{M g}(\mathbf{p p m})$ \\
\hline 8.45 & 10.7 & 1.43 & 1.06 & 2.29 & 1.66 & 15 & 6.2 \\
\hline
\end{tabular}

Araştırmada kullanılan Helios, Amaranthus caudatus'a ait tane tipi bir çeşit olup, yağ içeriği yüksektir (Yaroshko and Kuchuk, 2018; Anonim, 2020). Sterk çeşidi, Amaranthus paniculatus x Amaranthus nutans türlerinin melezlenmesi ve melezlenen tohumlara kimyasal mutagen uygulanması sonucu elde edilmiş bir çeşittir. Çeşit nem 
ve sıcaklık stresine dayanıklı olarak geliştirilmiştir (Jafari ve ark., 2018). Ultra çeşidi, Amaranthus hybridus türüne ait bir çeşit olup, kısa vejetasyonu olan bölgeler için geliştiriliştir. Ukrayna'da 1998 yılında tescil edilmiştir (Martirosyan, 2005; Goptsiy ve ark., 2008).

Deneme 2017 ve 2018 yıllarında ana parsellere yetiştirme şekli (kuru/sulu), alt parsellere çeşitler olmak üzere bölünmüş parseller deneme desenine göre 3 tekerrürlü olarak kurulmuştur. Parseller $3.5 \mathrm{~m} \times 2.8 \mathrm{~m}$ olmak üzere $9.8 \mathrm{~m}^{2}$ olarak hazırlanmıştır. Bloklar ve parseller arasında $1.5 \mathrm{~m}$ boşluk bırakılmıştır. Ekimler $70 \mathrm{~cm} \times 15 \mathrm{~cm}$ mesafeler bırakılarak, her iki yılda da 25 Mart'ta ekilmiştir. Ekim sırasında ve bitkiler $30 \mathrm{~cm}$ boya ulaştıklarında olmak üzere iki dönemde dekara 5'er $\mathrm{kg} \mathrm{N}$ hesabıyla \%21'lik amonyum sülfat gübresi, yine ekimle birlikte dekara saf olarak $5 \mathrm{~kg} \mathrm{P} \mathrm{P}_{5}$ hesabıyla \%39-41'lik triple süper fosfat gübresi uygulanmıştır. Kuru şartlarda herhangi bir sulama yapılmamış, sulu şartlarda ise bitkinin çiçek açmasından öncesine kadar yağmurlama sulama sistemiyle, sonrasında ise salma sulama sistemiyle sulamalar yapılmıştır. Tohumlar bitkiler kurumaya başladığı ve salkımlar elle ovuşturulduğunda dökülmeye başladığı dönemde hasat edilmiştir. Denemenin birinci yılında (2017 yılı) Ultra çeşidi kuru şartlarda 08.08.2017, sulu şartlarda ise 13.08.2017 tarihinde hasat edilmiştir. Diğer taraftan Sterk ve Helios çeşitleri ise kuru ve sulu şartlarda 11.10.2017 tarihinde hasatları yapılımışıı. Denemenin ikinci yılında (2018 yılı) ise tüm çeşitler kuru ve sulu koşullarında 30.10.2018 tarihinde tohum için hasat edilmiştir.

Her bir parselde kenar tesirleri (parsel kenarlarından birer sıra ve parsel başlarında $50 \mathrm{~cm}$ ) atılıktan sonra kalan bitkilerin bağ makası ile kesilerek hasat yapıımış ve tüm bitkiler açık havada kurumaya bırakılmıştır. Kuruyan bitkiler harman edilerek tohumları ayrılmıştır ve geri kalan tüm bitki kısımları saman olarak adlandırılmıştır (McDonald ve ark., 2011). Amarant tohum ve samanları $70{ }^{\circ} \mathrm{C}$ ayarlı etüvde ağırlıkları sabitleşinceye kadar kurumaya bırakılmıştır (Öncel ve ark., 2004; Karabulut ve Canbolat, 2005). Kurutulan tohum ve samanlar 1 mm'lik elek çapına sahip öğütme değirmeninde öğütülmüştür.

Öğütülen tohum ve samanlarda mikro Kjeldahl metoduna göre toplam azot tayinleri yapılmış ve bulunan azot miktarı 6.25 katsayısı ile çarpılarak ham protein oranları belirlenmiştir (AOAC, 1997). Ögüutülmüş tohum ve samanlarda NDF ve ADF miktarları Van Soest ve ark. (1991) tarafından tavsiye edilen metot kullanılarak belirlenmiştir. NDF ve ADF miktarlarından yararlanılarak KMS=88.9-(0.779 x \%ADF) (Oddy ve ark., 1983); KMT= 120/(\%NDF) (Sheaffer ve ark., 1995); SE= $0.27+0.0428$ x (\% KMS) (Fonnesbeck ve ark., 1984); ME= $0.821 \times$ SE (Mcal kg-1) (Khalil ve ark., 1986); NYD= (KMS x KMT) /1.29 Sheaffer ve ark. (1995)'ın önerdikleri formüllerle belirlenmiştir.

Deneme verileri JMP 5.0.1 istatistik paket programı kullanılarak varyans analizleri hesaplanmış ve önemli çıkan ortalamalar $\mathrm{LSD}_{(0.05)}$ çoklu karşılaştırma testine göre gruplandırılmıştır.

\section{BULGULAR VE TARTIŞMA}

Sulu ve kuru şartlarda iki yıl süreyle yetiştirilen Helios, Sterk, ve Ultra çeşitlerinin tohumlarının HP oranı ile samanın yem kalite değerlerine ait verilere yapılan varyans analizi sonucu hesaplanan LSD değerleri ve önemlilikleri Çizelge 3'de verilmiştir. Çizelge 3 incelendiğinde tohum HP oranı (yıl, yetiştirme şekli ile yetiştirme şekli x çeşit interaksiyonu hariç), saman HP oranı (yıl x yetiştirme şekli interaksiyonu hariç), saman NDF oranı (yıl ile yıl $x$ yetiştirme şekli $x$ çeşit İnteraksiyonu hariç), saman ADF oranı, saman KMS oranı, saman KMT oranı (yıl $x$ yetiştirme şekli interaksiyonu ve yı $x$ yetiştirme şekli $x$ çeşit İnteraksiyonu hariç), saman SE, saman ME ve saman NYD değeri (yıl, yıl x yetiştirme şekli interaksiyonu ve yıl $x$ yetiştirme şekli $x$ çeşit İnteraksiyonu hariç) üzerine varyasyon kaynaklarının etkileri önemli bulunmuştur.

Çizelge 3. Araştırmada incelenen tohum ve saman özelliklerine ait LSD değerleri ve önemlilik durumları. Table 3. LSD values and significance of seed and straw characteristics examined in the study.

\begin{tabular}{|c|c|c|c|c|c|c|c|c|c|}
\hline Varyasyon kaynakları & $\begin{array}{l}\text { Tohum } \\
\text { (HP) } \\
(\%) \\
\end{array}$ & $\begin{array}{l}\text { Saman } \\
\text { (HP) (\%) }\end{array}$ & $\begin{array}{l}\text { Saman } \\
\text { NDF } \\
(\%)\end{array}$ & $\begin{array}{l}\text { Saman } \\
\text { ADF } \\
(\%)\end{array}$ & $\begin{array}{l}\text { Saman } \\
\text { KMS } \\
(\%)\end{array}$ & $\begin{array}{l}\text { Saman } \\
\text { KMT } \\
(\%) \\
\end{array}$ & $\begin{array}{l}\text { Saman } \\
\text { SE } \\
(\text { Mcal kg-1) }\end{array}$ & $\begin{array}{l}\text { Saman } \\
\text { ME } \\
(\text { Mcal kg-1) }\end{array}$ & $\begin{array}{l}\text { Saman } \\
\text { NYD }\end{array}$ \\
\hline Yıl & öd & $0.44^{\star \star}$ & öd & $0.21^{* *}$ & $0.12^{\star *}$ & $0.04^{*}$ & $0.010^{* \star}$ & $0.006^{* *}$ & öd \\
\hline Yetiştirme şekli & öd & $0.64^{\star *}$ & $3.37^{* *}$ & $1.02^{\star *}$ & $0.75^{\star *}$ & $1.19 * *$ & $0.034^{\star *}$ & $0.024^{* *}$ & $10.7^{\star \star}$ \\
\hline Yıl x Yetiştirme şekli İnt. & $0.51^{*}$ & öd & $1.21^{\star}$ & $0.80^{\star *}$ & $0.62^{*}$ & öd & $0.027^{*}$ & $0.021^{* *}$ & öd \\
\hline Çeşit & $0.44^{*}$ & $0.61^{\star *}$ & $1.05^{\star *}$ & $0.69 * \star$ & $0.54^{\star *}$ & $0.05^{\star *}$ & $0.023^{\star *}$ & $0.019 * *$ & $3.2^{\star *}$ \\
\hline Yıl x Çeşit İnt. & $0.63^{*}$ & $0.86^{* *}$ & $1.49^{* *}$ & $0.98^{\star *}$ & $0.76^{* *}$ & $0.07^{\star *}$ & $0.033^{* *}$ & $0.026^{* *}$ & $4.5^{\star *}$ \\
\hline Yetiştirme şekli x Çeşit İnt. & öd & $0.86^{* *}$ & $1.49 * *$ & $0.98^{* *}$ & $0.76^{\star *}$ & $0.07^{* *}$ & $0.033^{* *}$ & $0.026^{* *}$ & $4.5^{\star \star}$ \\
\hline Yıl x Yetiştirme şekli x Çeşit İnt. & $0.88^{* *}$ & $1.22^{*}$ & öd & $1.39 *$ & $1.08^{\star}$ & öd & $0.046^{*}$ & $0.037^{*}$ & öd \\
\hline
\end{tabular}

**: \%1 ihtimal seviyesinde, *: \%5 ihtimal seviyesinde önemlidir. öd: Önemli değil. 


\section{Tohumda Ham Protein Oranı (\%)}

Yem kaynaklarında yüksek miktarlarda olması istenen proteinler hayvanların gelişmesi, büyümesi ve doku onarımları üzerine olumlu etkileri bulunmaktadır. Hayvanların yeterli miktarda protein alamaması durumunda büyüme ve gelişmede gerilemeler görülecektir. Protein hayvanların yumurta, süt, et, yapağı ve tüy gelişmesine doğrudan etkilidir (Kutlu ve ark., 2005). Diğer taraftan protein ihtiyaçlarına ilave olarak enerji ihtiyaçlarının da karşılanması hayvanlardan beklenen verim düzeyine ulaşılacak ve hayvanların daha sağlıklı gelişmesini sağlayacaktır (Kutlu ve Özen, 2009).

Sulu ve kuru şartlarda yetiştirilen Amarant çeşitlerinin tohumda ham protein oranları Çizelge 4'de verilmiştir. Çizelge 4 incelendiğinde tohum ham protein içeriği 2017 yılında \%16.03, 2018 yılında ise \%15.78 olarak belirlenmiş olup yıllar arasında önemli bir fark görülmemiştir. 2017 ve 2018 yılları arasında nem sıcaklık ve yağış yönünden farklılık olmasına rağmen bu farklılıkların tohum ham protein içeriğinde önemli bir değişime neden olmadığı görülmüştür.

Amarant çeşitlerinin tohumunda kuru şartlarda \%15.65, sulu şartlarda ise \%16.16 ham protein belirlenmiş olup kuru ve sulu şartların tohumdaki ham protein içeriğine etkileri önemli olmamıştır. Benzer olarak kinoa üzerine yapılan bir araştırmada tohum ham protein içeriği kuru şartlarda \%12.37, sulu şartlarda ise \%12.62 olarak belirlenmiş ve yetiştirme şeklinin tohumdaki ham protein içeriği üzerine etkisinin olmadığı bildirilmiştir (Kır, 2016; Kır ve Temel 2016; Kır ve Temel 2017). Diğer taraftan, Selçuk (2011) ise yaptığı bir araştırmada amarant çeşitlerinin tohum azot içeriğini sulu şartlarda yetiştirilmesi durumunda daha yüksek, kurak şartlarda ise daha düşük bulmuştur.

Amarant çeşitlerinin tohum ham protein içeriklerinde istatistiksel olarak önemli bir değişiklik görülmüştür. En yüksek tohum ham protein içeriği \% 16.26 ile Ultra çeşidinde, en düşük tohum ham protein içeriği ise \%15.58 ile Sterk çeşidinde belirlenmiştir. Amarant çeşitlerinin genetik özelliklerinin farklı olması tohumlarının içerdiği ham protein miktarında da farklılıklara sebep olmuştur. Amarant çeşitleri üzerine yapılan bir çok çalışmada tohum ham protein oranları \%13-21 (Berghofer ve ark., 2002), \%16.6 (Arendt ve ark., 2013), \%12.5-16.0 (Venskutonis ve Kraujalis, 2013), \%15.22-18.55 (Gimplinger ve ark., 2007), \%14-18 (Aufhammer ve ark 1999), \%18.5-20.1 (Jamriska, 1996), \%16.2-16.3 (Pospisil ve ark., 2006), \%12.35-18.42 (Olaniyi ve ark., 2008), \%15.1-15.4 (Svirskis, 2003) aralıklarında belirlenmiştir. Diğer taraftan alternatif bir bitki olan kinoa üzerine yapılan bir araştırmada çeşitlerin ortalaması olarak tohum ham protein içeriği \%12.62 (Kır ve Temel, 2016) ve \%15.0 (Keskin ve Önkür, 2019) olarak belirlenmiştir. Diğer alternatif bitkilerle de kıyaslandığında amarant bitkisinin tohumlarındaki ham protein içeriğinin yüksek olduğu görülmektedir.

İki yıl yürütülen araştırmada yıllara, çeşitlere ve yetiştirme şekline göre Amarant tohumlarının ham protein içeriklerinde \%15.10 ile \%16.93 arasında değişmiştir. Yıl, yetiştirme şekli ve çeşitler birlikte değerlendirildiğinde en yüksek tohum ham protein içeriği \%16.93 ile 2018 yılında sulu şartlarda yetiştirilen Ultra çeşidinde, en düşük tohum ham protein oranı \%15.10 ile 2018 yılında sulu şartlarda yetiştirilen Sterk çeşidinde belirlenmiştir.

Çizelge 4. Yıl, yetiştirme şekli ve Amarant çeşitlerine göre tohum ham protein oranları (\%).

Table 4. According to year, cultivation conditions (dry/irrigation) and Amarant varieties, seed crude protein ratio (\%).

\begin{tabular}{|c|c|c|c|c|c|}
\hline \multirow[b]{2}{*}{ Yillar } & \multicolumn{5}{|c|}{ Çeşitler } \\
\hline & Yetiştirme şekli & Helios & Sterk & Ultra & Yıl ort. \\
\hline \multirow{2}{*}{2017} & Kuru & $15.50 \mathrm{cde}^{*}$ & $15.23 \mathrm{cde}$ & $16.03 \mathrm{bcd}$ & 16.03 \\
\hline & Sulu & $16.50 \mathrm{ab}$ & $16.83 a b$ & $16.10 \mathrm{abc}$ & \\
\hline \multirow{2}{*}{2018} & Kuru & $16.03 \mathrm{bcd}$ & $15.17 \mathrm{de}$ & 15.97 bcde & 15.78 \\
\hline & Sulu & 15.50 cde & $15.10 \mathrm{e}$ & $16.93 \mathrm{a}$ & \\
\hline \multicolumn{2}{|c|}{ Çeşit ort. } & $15.88 \mathrm{ab}$ & $15.58 \mathrm{~b}$ & $16.26 \mathrm{a}$ & \\
\hline \multicolumn{2}{|c|}{ Yetiştirme şekli ort. } & Kuru: 15.65 & & Sulu: 16.16 & \\
\hline
\end{tabular}

${ }^{\star}$ Aynı harflerle gösterilen değerler arasındaki fark istatistiksel olarak önemli değildir.

\section{Samanda Ham Protein Oranı (\%)}

Amarant çeşitlerinin samanlarındaki ham protein oranları yıllara, çeşitlere ve yetiştirme şekline göre önemli farklar göstermiştir (Çizelge 5). Araştırmanın birinci yılı (2017)'nda saman ham protein içeriği \%5.59 olurken, ikinci yılı (2018)'nda \%6.51 olarak tespit edilmiştir. Araştırmanın ikinci yılında yağış, sıcaklık ve nem miktarı daha yüksek olması nedeniyle bitkinin yaprak ve dallanma sayısını artırması samanda ham protein içeriğinin de yüksek çıkmasına neden olduğu tahmin edilmektedir.

Amarant çeşitlerinin sulu şartlarda yetiştirilmesi çeşitlerin saman ham protein içeriklerinde artışlara neden olmuştur. Sulu şartlarda saman ham protein içeriği \%7.91 iken, kuru şartlarda yetiştirilen amarant çeşitlerinin saman ham protein içerikleri \%4.19 olarak belirlenmiştir. Kır (2016) Kinoa bitkisi ile yaptığı bir araştırmada saman ham protein içeriğine kuru ve sulu şartlarda yetiştirmenin etkisini önemsiz bulurken, Selçuk (2011) da amarant 
bitkisi ile yaptığı bir araştırmada saman kısımlarının azot içeriğinin sulu şartlarda daha yüksek, kurak şartlarda ise daha düşük olduklarını belirlemiştir. Araştırma bulgularımız Selçuk (2011) tarafından yapılan araştırma sonuçlarına benzerlik göstermektedir.

Çeşitler arasında en yüksek samanda ham protein içeriği \%7.61 ile Helios çeşidinde, en düşük oran ise \%4.48 ile Ultra çeşidinde belirlenmiştir. Farklı Amarant çeşitleri üzerine yapılan araştırmalarda saman ham protein içeriği \%2.55 ile \%4.62 (Olaniyi ve ark., 2008) ve \%5.9 ile \%7.1 (Svirskis, 2003) arasında belirlenmiştir. Diğer bazı tahıl, baklagil ve alternatif yem bitkileri üzerine yapılan araştırmalarda saman ham protein içerikleri Salsola rutenica'da (tohum hasat döneminde) \%6.21 (Temel ve Keskin, 2019b), Astragallus gummifer'de (tohum hasat döneminde) \%3.82 (Demir ve Keskin, 2016), Atraphaxis spinosa' da (tohum hasat döneminde) \%6.95 (Karakuş ve Keskin, 2018), Sorghum sp.'de \%5.9 ile \%8.88 (Temel ve ark., 2017), Chenopodium quinoa'da \%5.0 (Keskin ve Önkür, 2019) ve \%5.44 (Kır ve Temel, 2016), Triticum aestivum'da \%3.0 ile \%3.63 (Yavuz, 2005; Sehu ve ark., 1996; Nurfeta ve ark., 2007; Güngör ve ark., 2008) arasında belirlenmiştir. Yapılan araştırmalar incelendiğinde araştırmada kullanılan Amarant çeşitlerinin, birçok tahıl, baklagil ve alternatif yem bitkilerinin samanlarında bulunan ham protein içeriklerinden daha fazla ham protein içerdikleri görülmektedir.

Yıl, çeşit ve yetiştirme şekli interaksiyonuna göre en yüksek saman ham protein içeriği \%11.26 ile 2018 yılında sulu şartlarda yetiştirilen Helios çeşidinde tespit edilmiştir.

Çizelge 5. Yıl, yetiştirme şekli ve Amarant çeşitlerine göre saman ham protein oranları (\%).

Table 5. According to year, cultivation conditions (dry/irrigation) and Amarant varieties, straw crude protein ratio (\%).

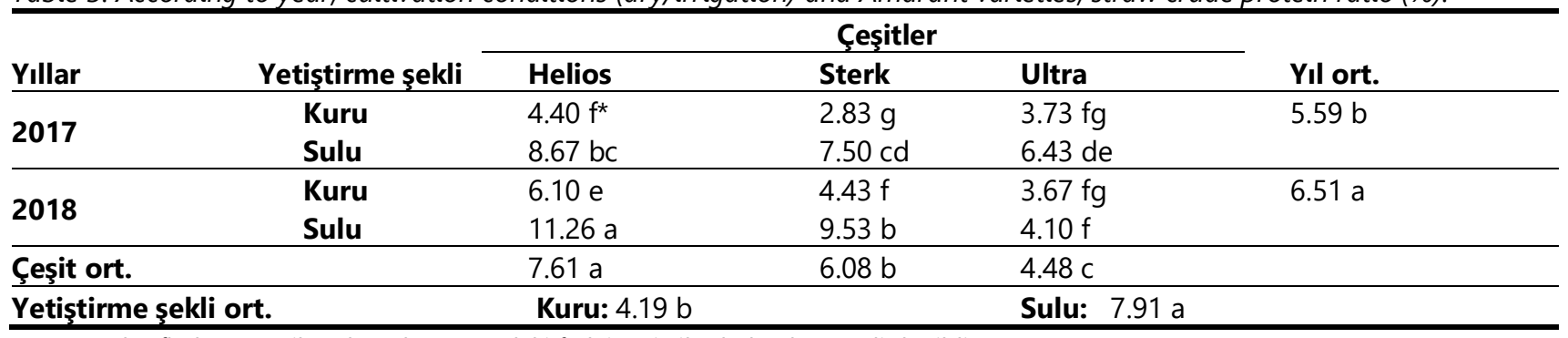

*Aynı harflerle gösterilen değerler arasındaki fark istatistiksel olarak önemli değildir.

\section{Samanda NDF Oranı (\%)}

Neutral Detergent Fiber (NDF) hücre duvarında lifli karbonhidratlar (selüloz ve hemiselüloz), lignin ve sıcaklıkla zarar görmüş proteinleri ve silisyumu içerir. NDF yemin özgül ağırlığının da iyi bir göstergedir. Sindirim sisteminin hacimsel kapasitesi dikkate alındığında, yemdeki NDF miktarı ile hayvanların yem tüketimi arasında da ilişki bulunmaktadır (Kutlu ve ark., 2005).

Yıllara bağlı olarak 2017 yılında saman NDF içeriği \%51.8 ve 2018 yılında ise saman NDF içeriği \%51.9 olarak gerçekleşmiş olup yıllar arasında saman NDF içeriklerinde önemli bir değişiklik olmamıştır.

Kuru şartlarda yetiştirilen amarant çeşitlerinin saman NDF içeriği \%47.7, sulu şartlarda yetiştirilen amarant çeşitlerinin saman NDF içerikleri ise \%56.1 olarak belirlenmiştir. Amarant çeşitlerinin kuru şartlarda yetiştirilmesi saman NDF oranında düşüşlere neden olduğu görülmüştür.

Araştırmada kullanılan Helios, Sterk ve Ultra çeşitlerinin saman NDF içerikleri sırasıyla \%48.1, \%46.9 ve \%60.7 olmuştur. Çeşitlerin saman NDF içeriklerinde önemli farklar olduğu görülmüştür. En düşük saman NDF oranı \%48.1 ile Helios çeşidinde, en yüksek saman NDF oranı \%60.7 ile Ultra çeşidinde tespit edilmiştir. Yapılan bir araştırmada amarant çeşitleri NDF oranlarını \%47.8 ile \%47.5 arasında belirlemişlerdir (Pospisil ve ark., 2009). Bazı tahıl, baklagil ve alternatif yem bitkileri üzerine yapılan araştırmalarda saman NDF oranları Salsola rutenica'da \%76.75 (Temel ve Keskin, 2019b), Astragallus gummifer'de \%74.47 (Demir ve Keskin, 2016), Atraphaxis spinosa'da \%60.72 (Karakuş ve Keskin, 2018), Chenopodium quinoa'da \%70.8 (Keskin ve Önkür, 2019), Triticum aestivum'da \%84.9 (Yavuz, 2005), Oryza sativa'da \%79.0 (Maneerat ve ark., 2015), Triticum aestivum'da \%84.0, Hordeum vulgare'de \%85.9, Avena sativa'da \%69.7, Oryza sativa'da \%72.1 (Şehu ve ark., 1996), Triticum aestivum'da \%74.3 (Nurfeta ve ark., 2007) olarak tespit etmişlerdir. Ayrıca kuru ot ve silaj olarak hasat edilen bazı yem bitkilerinde de NDF oranları Vicia sativa'da \%40.63 ile \%47.27 (Temel ve ark, 2015), Chenopodium quinoa'da \%41.2 (Temel ve Keskin, 2019a), Zea mays'da \%40.24 ile \%54.16 (Akdeniz ve ark., 2017), Sorghum sp'de \%51.98 ile \%65.64 (Temel ve ark., 2017), Medicago sativa'da \%46.7 ile \%54.4 (Yavuz, 2005; Şehu ve ark., 2015) olarak belirlemişlerdir. Hem saman hem de kuru otlardaki NDF içerikleri ile karşılaştırıldığında amarant çeşitlerdeki NDF oranlarının önemli derecede düşük olduğu ve hayvan beslemede yararlı bir yem kaynağı olacağı görülmektedir. 
Yıl, çeşit ve yetiştirme şekli interaksiyonuna göre saman NDF içerikleri \%39.9 ile \%66.4 arasında değişmiştir. En düşük saman NDF oranı \%39.9 ile 2018 yılında kuru şartlarda yetiştirilen Sterk çeşidinde, en yüksek saman NDF oranı ise \%66.4 ile 2018 yılında sulu şartlarda yetiştirilen Ultra çeşidinde tespit edilmiştir (Çizelge 6).

Çizelge 6. Yıl, yetiştirme şekli ve Amarant çeşitlerine göre saman NDF oranları (\%).

Table 6. According to year, cultivation conditions (dry/irrigation) and Amarant varieties, straw NDF ratio (\%).

\begin{tabular}{|c|c|c|c|c|c|}
\hline \multirow[b]{2}{*}{ Yıllar } & \multirow[b]{2}{*}{ Yetiştirme şekli } & \multicolumn{3}{|c|}{ Çeşitler } & \multirow[b]{2}{*}{ Yıl ort. } \\
\hline & & Helios & Sterk & Ultra & \\
\hline \multirow{2}{*}{2017} & Kuru & 45.2 & 41.2 & 55.2 & 51.8 \\
\hline & Sulu & 55.9 & 56.2 & 57.4 & \\
\hline \multirow{2}{*}{2018} & Kuru & 40.7 & 39.9 & 63.9 & 51.9 \\
\hline & Sulu & 50.5 & 50.1 & 66.4 & \\
\hline Çeşit ort. & & $48.1 b^{*}$ & $46.9 \mathrm{c}$ & $60.7 \mathrm{a}$ & \\
\hline Yetiştirme şekli ort. & & Kuru: 47.7 b & & Sulu: & \\
\hline
\end{tabular}

*Aynı harflerle gösterilen değerler arasındaki fark istatistiksel olarak önemli değildir.

\section{Samanda ADF Oranı (\%)}

NDF içerisinden hemi-selüloz çıkartılarak Acid Detergent Fiber (ADF) elde edilir. ADF yemin sindirilebilirliği ve hayvanın enerji alımı konusunda fikir vermektedir (Kutlu ve ark., 2005).

Amarantların saman ADF içeriklerinde yıllara, çeşitlere ve yetiştirme şekline göre önemli farklılıklar olmuştur. Araştırmanın ikinci yılında (2018 yılı) daha yüksek saman ADF (\%38.7) içeriği, birinci yılda (2017 yılı) ise daha düşük saman ADF (\%37.0) içeriği belirlenmiştir.

Kuru ve sulu şartlarda amarant yetiştirilmesi saman ADF içeriklerini önemli derecede etkilemiştir. Buna göre sulu şartlarda yetiştirilen amarantların saman ADF (\%41.2) içeriği, kuru şartlarda yetiştirilen amarant saman ADF (\%34.6) içeriklerinden daha yüksek tespit edilmiştir (Çizelge 7).

Saman ADF içerikleri Helios, Sterk ve Ultra çeşitlerinde sırasıyla \%33.4, \%35.3 ve \%44.9 olmuştur. Saman NDF içerikleri bakımından çeşitler arasında önemli değişiklikler olduğu tespit edilmiştir. En düşük saman ADF oranı \%33.4 ile Helios çeşidinde, en yüksek saman ADF oranı \%44.9 ile Ultra çeşidinde tespit edilmiştir. Yapılan bir araştırmada amarant çeşitlerinin çiçeklenme dönemindeki ADF içeriği \%34.1 ile \%36.4 arasında değiştiğini ve aynı araştırmada kullanılan Sorghum sp. bitkisinden daha düşük oranda ADF içeriklerine sahip olduğunu belirlemişlerdir (Pospisil ve ark., 2009). Bazı tahıl, baklagil ve alternatif yem bitkileri üzerine yapılan araştırmalarda saman ADF oranlarını Salsola rutenica'da \%44.36 (Temel ve Keskin, 2019b), Astragallus gummifer'de \%57.84 (Demir ve Keskin, 2016), Atraphaxis spinosa'da \%24.9 (Karakuş ve Keskin, 2018), Chenopodium quinoa'da \%47.7 (Keskin ve Önkür, 2019), Triticum aestivum'da \%57.1 (Yavuz, 2005), Oryza sativa'da \%55.0 (Maneerat ve ark., 2015), Triticum aestivum'da \%51.2, Hordeum vulgare'de \%45.2, Avena sativa'da \%39.1, Oryza sativa'da \%36.8 (Şehu ve ark., 1996), Triticum aestivum'da \%49.5 ve \%57.50 (Nurfeta ve ark., 2007; Güngör ve ark., 2008) olarak tespit etmişlerdir. Ayrıca kuru ot ve silaj olarak hasat edilen bazı yem bitkilerinde de ADF oranları Vicia sativa' da \%28.94 ile \%35.71 (Temel ve ark ", 2015), Chenopodium quinoa'da \%24.9 (Temel ve Keskin, 2019a), Zea mays'da \%20.03 ile \%28.30 (Akdeniz ve ark., 2017), Sorghum sp'de \%27.94 ile \%40.44 (Temel ve ark., 2017), Medicago sativa'da \%37.3 ve \%40.1 (Yavuz, 2005; Şehu ve ark., 2015) olarak belirlemişlerdir. Birçok yem bitkisi tür ve çeşitleri ile karşılaştıııldığında Amarant çeşitlerinin ADF içeriklerinin düşük olduğu görülmektedir.

Çizelge 7. Yıl, yetiştirme şekli ve Amarant çeşitlerine göre saman ADF oranları (\%).

Table 7. According to year, cultivation conditions (dry/irrigation) and Amarant varieties, straw ADF ratio (\%).

\begin{tabular}{|c|c|c|c|c|c|}
\hline \multirow[b]{2}{*}{ Yıllar } & \multirow[b]{2}{*}{ Yetiştirme şekli } & \multicolumn{3}{|c|}{ Çeşitler } & \multirow[b]{2}{*}{ Yıl ort. } \\
\hline & & Helios & Sterk & Ultra & \\
\hline \multirow{2}{*}{2017} & Kuru & $30.2 f^{*}$ & $29.9 \mathrm{f}$ & $40.0 \mathrm{~d}$ & \multirow{2}{*}{$37.0 \mathrm{~b}$} \\
\hline & Sulu & $37.3 \mathrm{e}$ & $41.5 \mathrm{c}$ & $43.2 \mathrm{~b}$ & \\
\hline \multirow{2}{*}{2018} & Kuru & $29.5 \mathrm{f}$ & $29.4 \mathrm{f}$ & $48.5 \mathrm{a}$ & \multirow{2}{*}{$38.7 \mathrm{a}$} \\
\hline & Sulu & $36.6 \mathrm{e}$ & $40.5 \mathrm{~cd}$ & $47.9 \mathrm{a}$ & \\
\hline Çeşit ort. & & $33.4 \mathrm{c}$ & $35.3 \mathrm{~b}$ & $44.9 \mathrm{a}$ & \\
\hline Yetiştirme & & Kuru: 34.6 b & & Sulu: $41.2 \mathrm{a}$ & \\
\hline
\end{tabular}

*Aynı harflerle gösterilen değerler arasındaki fark istatistiksel olarak önemli değildir.

Yıl, yetiştirme şekli ve çeşitlerin saman ADF içerikleri üzerine interaksiyon etkileri önemli bulunmuştur. En düşük saman ADF içeriği \%29.4 ile 2018 yılında kuru şartlarda Sterk çeşidinin ekilmesiyle, en yüksek saman ADF içeriği ise \%48.5 ve \%47.9 ile 2018 yllında Ultra çeşidinin kuru ve sulu şartlarda yetiştirilmesiyle elde edildiği görülmektedir (Çizelge 7). 


\section{Samanda KMS Oranı (\%)}

Yıllara, çeşitlere ve yetiştirme şekline göre amaratların saman KMS içeriklerinde önemli değişimler olmuştur. En yüksek saman KMS içeriği \%60.1 ile 2018 yılında, \%61.9 ile kuru şartlarda ve \%62.9 ile Helios çeşidinde belirlenmiştir. Sulu şartlarda amarant çeşitlerinin ekilmesi saman KMS içeriklerinde düşüşlere neden olmuştur. Üçlü interaksiyona göre saman KMS içerikleri \%51.2 ile \%66.0 arasında değişmiştir. En yüksek saman KMS içeriği \%66.0, \%65.9, \%65.7 ve \%65.4 ile kuru şartlarda yetiştirilen Helios ve Sterk çeşitlerinde belirlenmiştir (Çizelge 8).

Saman KMS içerikleri Helios, Sterk ve Ultra çeşitlerinde sırasıyla \%62.9, \%61.4 ve \%54.0 olmuştur. Saman KMS içerikleri bakımından çeşitler arasında önemli değişiklikler olduğu tespit edilmiştir. En yüksek saman KMS oranı \%62.9 ile Helios çeşidinde, en düşük saman KMS oranı \%54.0 ile Ultra çeşidinde tespit edilmiştir. Bazı tahıl, baklagil ve alternatif yem bitkileri üzerine yapılan araştırmalarda saman KMS oranlarını Salsola rutenica'da \%54.34 (Temel ve Keskin, 2019b), Astragallus gummifer' de \%43.83 (Demir ve Keskin, 2016), Atraphaxis spinosa'da \%61.32 (Karakuş ve Keskin, 2018) olarak tespit etmişlerdir. Ayrıca kuru ot ve silaj olarak hasat edilen bazı yem bitkilerinde de KMS oranları Vicia sativa'da \%61.08 ile \%66.35 (Temel ve ark, 2015), Chenopodium quinoa'da \%69.5 (Temel ve Keskin, 2019a), Zea mays'da \%66.8 ile \%73.3 (Akdeniz ve ark., 2017), Sorghum sp'de \%57.39 ile \%67.13 (Temel ve ark., 2017) olarak belirlemişlerdir. Diğer birçok yem bitkisi otu ve samanı ile kıyaslandığında, Amarant çeşitlerinin KMS oranı bakımından yem olarak tavsiye edilecek bir tür olarak görülmektedir.

Çizelge 8. Yıl, yetiştirme şekli ve Amarant çeşitlerine göre saman KMS oranları (\%).

Table 8. According to year, cultivation conditions (dry/irrigation) and Amarant varieties, straw DMD ratio (\%).

\begin{tabular}{|c|c|c|c|c|c|}
\hline \multirow[b]{2}{*}{ Yıllar } & \multirow[b]{2}{*}{ Yetiştirme şekli } & \multicolumn{3}{|c|}{ Çeşitler } & \multirow[b]{2}{*}{ YIl ort. } \\
\hline & & Helios & Sterk & Ultra & \\
\hline \multirow{2}{*}{2017} & Kuru & $65.4 a^{*}$ & 65.7 a & $57.8 \mathrm{c}$ & \multirow{2}{*}{$60.1 \mathrm{a}$} \\
\hline & Sulu & $59.9 \mathrm{~b}$ & $56.6 \mathrm{~d}$ & $55.3 \mathrm{e}$ & \\
\hline \multirow{2}{*}{2018} & Kuru & $65.9 \mathrm{a}$ & 66.0 a & $51.2 \mathrm{f}$ & \multirow{2}{*}{$58.7 \mathrm{~b}$} \\
\hline & Sulu & $60.4 \mathrm{~b}$ & $57.3 \mathrm{~cd}$ & $51.6 \mathrm{f}$ & \\
\hline \multicolumn{2}{|c|}{ Çeşit ort. } & $62.9 \mathrm{a}$ & $61.4 \mathrm{~b}$ & $54.0 \mathrm{c}$ & \\
\hline \multicolumn{2}{|c|}{ Yetiştirme şekli ort. } & Kuru: $61.9 \mathrm{a}$ & & Sulu: $56.8 \mathrm{~b}$ & \\
\hline
\end{tabular}

*Aynı harflerle gösterilen değerler arasındaki fark istatistiksel olarak önemli değildir.

\section{Samanda KMT Oranı (\%)}

Saman KMT oranlarına ait değerler Çizelge 9'da verilmiştir. Çizelge 9'a göre saman KMT oranlarında yıllara, çeşitlere ve yetiştirme şekline göre önemli derecede farklılıklar görülmüştür. En yüksek saman KMT oranı \%2.40 ile 2018 yılında, \%2.61 ile Sterk çeşidinde ve \%2.59 ile kuru şartlarda yetiştirilen amarantlarda belirlenmiştir. Amarant bitkilerini sulu şartlarda yetiştirilmesi saman KMT içeriklerinin düşmesine neden olduğu belirlenmiştir. Yıl, yetiştirme şekli ve çeşit interaksiyonuna göre en yüksek KMT oranı \%3.00, \%2.95 ve \%2.91 ile sırasıyla 2018 yılında kuru şartlarda yetiştirilen Sterk çeşidinde, 2018 yılında kuru şartlarda yetiştirilen Helios çeşidinde ve 2017 yılında kuru şartlarda yetiştirilen Sterk çeşidinde belirlenmiştir.

Çizelge 9. Yıl, yetiştirme şekli ve Amarant çeşitlerine göre saman KMT oranları (\%).

Table 9. According to year, cultivation conditions (dry/irrigation) and Amarant varieties, straw DMI ratio (\%).

\begin{tabular}{|c|c|c|c|c|c|}
\hline \multirow[b]{2}{*}{ Yıllar } & \multirow[b]{2}{*}{ Yetiştirme şekli } & \multicolumn{3}{|c|}{ Çeşitler } & \multirow[b]{2}{*}{ Yıl ort. } \\
\hline & & Helios & Sterk & Ultra & \\
\hline \multirow{2}{*}{2017} & Kuru & $2.66 b^{*}$ & $2.91 \mathrm{a}$ & $2.17 \mathrm{~d}$ & \multirow{2}{*}{$2.35 \mathrm{~b}$} \\
\hline & Sulu & $2.15 \mathrm{~d}$ & $2.14 \mathrm{~d}$ & $2.09 \mathrm{~d}$ & \\
\hline \multirow{2}{*}{2018} & Kuru & $2.95 \mathrm{a}$ & $3.00 \mathrm{a}$ & $1.88 \mathrm{e}$ & \multirow{2}{*}{$2.40 \mathrm{a}$} \\
\hline & Sulu & $2.38 \mathrm{c}$ & $2.39 \mathrm{c}$ & $1.81 \mathrm{e}$ & \\
\hline Çeşit ort. & & $2.53 \mathrm{~b}$ & $2.61 \mathrm{a}$ & $1.99 \mathrm{c}$ & \\
\hline Yetiştirme şekli ort. & & Kuru: 2 & & Sulu: & \\
\hline
\end{tabular}

*Aynı harflerle gösterilen değerler arasındaki fark istatistiksel olarak önemli değildir.

Saman KMT içerikleri Helios, Sterk ve Ultra çeşitlerinde sırasıyla \%2.53, \%2.61 ve \%1.99 olmuştur. En yüksek saman KMT oranı \%2.61 ile Sterk çeşidinde, en düşük saman KMT oranı \%1.99 ile Ultra çeşidinde tespit edilmiştir. Bazı tahıl, baklagil ve alternatif yem bitkileri üzerine yapılan araştırmalarda saman KMT oranlarını Astragallus gummifer'de \%1.61 (Demir ve Keskin, 2016), Atraphaxis spinosa'da \%1.97 (Karakuş ve Keskin, 2018) olarak tespit edilmiştir. Ayrıca kuru ot ve silaj olarak hasat edilen bazı yem bitkilerinde de KMT oranları Chenopodium quinoa'da \%2.91 (Temel ve Keskin, 2019a), Zea mays'da \%2.22 ile \%2.99 (Akdeniz ve ark., 2017), Sorghum sp'de \%1.83 ile 
Keskin ve ark., Sulu ve Kuru Koşullarda Yem Üretim Amacıyla Yetiştirilen Bazı Amarant Çeşitlerinin Tohum ve Saman Kalite Özelliklerinin Belirlenmesi

\%2.31 (Temel ve ark., 2017) olarak belirlenmiştir. Birçok yem bitkisi otu ve samanı ile kıyaslandığında, Amarant çeşitlerinin saman KMT oranı bakımından hayvan yemi olabileceğini göstermektedir.

\section{Samanda SE Miktarı (Mcal $\mathrm{kg}^{-1}$ )}

Yemlerde bir miktar enerji hayvan gübresiyle dışarı atılmaktadır. Toplam enerjiden gübreyle atılan enerjinin çıkarılmasıyla kalan enerjiye sindirilebilir enerji (SE) denilmektedir (Kutlu ve ark., 2005).

Saman SE içeriği yıllara, yetiştirme şekline ve çeşitlere göre önemli miktarda değişimler olduğu belirlenmiştir. 2018 yılındaki SE miktarı $\left(2.78 \mathrm{Mcal} \mathrm{kg}^{-1}\right.$ )'na göre, 2017 yılındaki SE miktarı (2.84 Mcal kg $\left.{ }^{-1}\right)$, daha yüksek olmuştur. Çeşitler arasında en yüksek SE miktarı $2.96 \mathrm{Mcal} \mathrm{kg}^{-1}$ ile Helios çeşidinde, en düşük SE miktarı ise $2.58 \mathrm{Mcal} \mathrm{kg}^{-1}$ ile Ultra çeşidinde tespit edilmiştir. Amarant çeşitlerinin kuru şartlarda yetiştirilmesi SE miktar $\left(2.92 \mathrm{Mcal} \mathrm{kg}^{-1}\right)^{\prime} \mathrm{n} ı n$ daha yüksek olacağı belirlenmiştir. Üçlü interaksiyona göre SE miktarları $2.46 \mathrm{Mcal} \mathrm{kg}^{-1}$ ile $3.09 \mathrm{Mcal} \mathrm{kg}^{-1} \mathrm{arasında}^{-1}$ değişmiştir. En yüksek SE miktarı her iki yılda da kuru şartlarda yetiştirilen Helios ve Sterk çeşitlerinde tespit edilmiştir (Çizelge 10).

Çizelge 10. Yıl, yetiştirme şekli ve Amarant çeşitlerine göre saman SE miktarı (Mcal $\left.\mathrm{kg}^{-1}\right)$.

Table 10. According to year, cultivation conditions (dry/irrigation) and Amarant varieties, straw DE amount $\left(\right.$ Mcal kg $\left.{ }^{-1}\right)$.

\begin{tabular}{|c|c|c|c|c|c|}
\hline \multirow[b]{2}{*}{ Yıllar } & \multirow[b]{2}{*}{ Yetiştirme şekli } & \multicolumn{3}{|c|}{ Çeşitler } & \multirow[b]{2}{*}{ Yıl ort. } \\
\hline & & Helios & Sterk & Ultra & \\
\hline \multirow{2}{*}{2017} & Kuru & $3.07 a^{*}$ & $3.08 \mathrm{a}$ & $2.74 \mathrm{c}$ & \multirow{2}{*}{$2.84 \mathrm{a}$} \\
\hline & Sulu & $2.83 \mathrm{~b}$ & $2.69 \mathrm{~d}$ & $2.64 \mathrm{e}$ & \\
\hline \multirow{2}{*}{2018} & Kuru & $3.09 \mathrm{a}$ & $3.09 \mathrm{a}$ & $2.46 \mathrm{f}$ & \multirow{2}{*}{$2.78 \mathrm{~b}$} \\
\hline & Sulu & $2.86 \mathrm{~b}$ & $2.72 \mathrm{~cd}$ & $2.48 \mathrm{f}$ & \\
\hline Çeşit ort. & & $2.96 \mathrm{a}$ & $2.90 \mathrm{~b}$ & $2.58 \mathrm{c}$ & \\
\hline Yetiştirme şekli ort. & & Kuru: $2.92 \mathrm{a}$ & & Sulu: $2.70 \mathrm{~b}$ & \\
\hline
\end{tabular}

*Aynı harflerle gösterilen değerler arasındaki fark istatistiksel olarak önemli değildir.

Bazı tahıl, baklagil ve alternatif yem bitkileri üzerine yapılan araştırmalarda saman SE miktarı Salsola rutenica'da 2.60 Mcal kg ${ }^{-1}$ (Temel ve Keskin, 2019b), Astragallus gummifer'de $2.14 \mathrm{Mcal} \mathrm{kg}^{-1}$ (Demir ve Keskin, 2016), Atraphaxis spinosa' da $2.89 \mathrm{Mcal} \mathrm{kg}^{-1}$ (Karakuş ve Keskin, 2018) olarak tespit edilmiştir. Ayrıca kuru ot ve silaj olarak hasat edilen bazı yem bitkilerinde SE miktarı Vicia sativa' da $2.90 \mathrm{Mcal} \mathrm{kg}^{-1}$ ile $3.10 \mathrm{Mcal} \mathrm{kg}^{-1}$ (Temel ve ark, 2015), Chenopodium quinoa'da $3.24 \mathrm{Mcal} \mathrm{kg}^{-1}$ (Temel ve Keskin, 2019a), Zea mays'da $3.13 \mathrm{Mcal} \mathrm{kg}^{-1}$ ile $3.40 \mathrm{Mcal} \mathrm{kg}^{-1}$ (Akdeniz ve ark., 2017), Sorghum sp'de $2.72 \mathrm{Mcal} \mathrm{kg}^{-1}$ ile $3.14 \mathrm{Mcal} \mathrm{kg}^{-1}$ (Temel ve ark., 2017) olarak bulunmuştur. Yapılan araştırma sonuçlarından da görüleceği üzere bazı yem bitkisi otu ve samanı ile kıyaslandığında, Amarant çeşitlerinin saman SE miktarının yüksek olduğu görülmektedir.

\section{Samanda ME Miktarı (Mcal $\mathbf{k g}^{-1}$ )}

Sindirilebilen enerji miktarından bir miktar enerji idrar ve metan gazı ile dışarı atılmaktadır. Idrar ve metan gazı ile dışarı atılan bu enerji sindirilebilir enerjiden çıkarıldığında kalan enerji miktarına metabolik (metabolizable = çevrilebilir) enerji adı verilir (Kutlu ve ark., 2005).

Yetiştirme şekline göre Amarant çeşitlerinin saman ME miktarları Çizelge 11'de verilmiştir. Çizelge 11'e göre saman ME miktarları yıllara, yetiştirme şekline ve çeşitlere göre önemli miktarda farklılık göstermiştir. En yüksek SE miktarı $2.33 \mathrm{Mcal} \mathrm{kg}^{-1}$ ile 2017 yılında, $2.39 \mathrm{Mcal} \mathrm{kg}^{-1}$ ile kuru şartlarda ve 2.43 ile Helios çeşidinde tespit edilmiştir. Üçlü interaksiyona göre SE miktarları 2.02 ile $2.54 \mathrm{Mcal} \mathrm{kg}^{-1}$ arasında değişmiştir. En yüksek ME miktarları her iki yılda da sulu şartlarda yetiştirilen Helios ve Sterk çeşitlerinde tespit edilmiştir.

Yapılan araştırmalarda Salsola rutenica, Astragallus gummifer ve Atraphaxis spinosa bitkilerinin vejetasyon döneminin sonunda bitkinin kuruduğu dönemlerdeki ME miktarının $1.76 \mathrm{Mcal} \mathrm{kg}^{-1}$ ile $2.37 \mathrm{Mcal} \mathrm{kg}^{-1}$ arasında değiştiği belirlenmiştir (Temel ve Keskin, 2019a; Demir ve Keskin, 2016; Karakuş ve Keskin, 2018). Yine kuru ot ve silaj olarak yetiştirilen Vicia sativa, Chenopodium quinoa, Zea mays ve Sorghum sp. tür ve çeşitlerinde ME miktarı $2.23 \mathrm{Mcal} \mathrm{kg}^{-1}$ ile $2.79 \mathrm{Mcal} \mathrm{kg}^{-1}$ arasında bulunmuştur (Temel ve ark "2015; Temel ve Keskin, 2019b; Akdeniz ve ark., 2017; Temel ve ark., 2017). Araştırmalardan elde edilen sonuçlar bazı yem bitkisi otu ve samanı ile kıyaslandığında, amarant çeşitlerinin saman ME miktarının yüksek olduğunu göstermektedir. 
Keskin ve ark., Sulu ve Kuru Koşullarda Yem Üretim Amacıyla Yetiştirilen Bazı Amarant Çeşitlerinin Tohum ve Saman Kalite Özelliklerinin Belirlenmesi

Çizelge 11. Yıl, yetiştirme şekli ve Amarant çeşitlerine göre saman ME miktarı (Mcal kg ${ }^{-1}$ ).

Table 11. According to year, cultivation conditions (dry/irrigation) and Amarant varieties, straw ME amount (Mcal kg $\left.{ }^{-1}\right)$.

\begin{tabular}{|c|c|c|c|c|c|}
\hline \multirow[b]{2}{*}{ Yıllar } & \multirow[b]{2}{*}{ Yetiştirme şekli } & \multicolumn{3}{|c|}{ Çeşitler } & \multirow[b]{2}{*}{ Yıl ort } \\
\hline & & Helios & Sterk & Ultra & \\
\hline \multirow{2}{*}{2017} & Kuru & $2.52 a^{*}$ & $2.53 \mathrm{a}$ & $2.25 \mathrm{c}$ & \multirow{2}{*}{$2.33 \mathrm{a}$} \\
\hline & Sulu & $2.32 \mathrm{~b}$ & $2.21 \mathrm{~d}$ & $2.16 \mathrm{e}$ & \\
\hline \multirow{2}{*}{2018} & Kuru & $2.54 \mathrm{a}$ & $2.54 \mathrm{a}$ & $2.02 \mathrm{f}$ & \multirow{2}{*}{$2.28 \mathrm{~b}$} \\
\hline & Sulu & $2.35 \mathrm{~b}$ & $2.24 \mathrm{~cd}$ & $2.04 \mathrm{f}$ & \\
\hline Çeşit ort. & & $2.43 a$ & $2.38 \mathrm{~b}$ & $2.12 \mathrm{c}$ & \\
\hline Yetiştirme şekli ortalaması & & Kuru: 2 & & Sulu: & \\
\hline
\end{tabular}

*Aynı harflerle gösterilen değerler arasındaki fark istatistiksel olarak önemli değildir.

\section{Samanda NYD Değeri}

İki yıl süreyle yürütülen denemede yetiştirme şekline göre amarant çeşitlerinin saman NYD değerleri Çizelge 12 'de verilmiştir. Yıllara göre amarant çeşitlerinin saman NYD değerlerinde önemli bir fark olmamıştır. Diğer taraftan, yetiştirme şekline ve amarant çeşitlerine göre saman NYD değerleri arasında önemli farklar bulunmuştur. Kuru şartlarda yetiştirilen amarant çeşitlerinin saman NYD değerleri (126.5), sulu şartlarda yetiştirilen amarant çeşitlerinin saman NYD değeri (93.3)'nden daha yüksek bulunmuştur. Amarant çeşitlerinde en yüksek saman NYD değeri 125.6 ve 124.1 ile sırasıyla Sterk ve Helios çeşitlerinde belirlenmiştir. En düşük saman NYD değeri (83.4) ise Ultra çeşidinde tespit edilmiştir. Yıl, yetiştirme şekli ve çeşit birlikte değerlendirildiğinde en yüksek saman NYD değerleri kuru şartlarda yetiştirilen Helios ve Sterk çeşitlerinde bulunmuştur.

Bazı tahıl, baklagil ve alternatif yem bitkilerinin saman NYD değerleri Salsola rutenica'da 65.92 (Temel ve Keskin, 2019b), Astragallus gummifer'de 55.04 (Demir ve Keskin, 2016), Atraphaxis spinosa'da 97.3 (Karakuş ve Keskin, 2018), Chenopodium quinoa'da 68.6 (Keskin ve Önkür, 2019), Triticum aestivum'da 46.6 (Yavuz, 2005) olarak tespit edilmiştir. Ayrıca kuru ot ve silaj olarak hasat edilen bazı yem bitkilerinde de NYD değerleri Vicia sativa'da 121.75 ile 149.90 (Temel ve ark, 2015), Chenopodium quinoa'da 156.8 (Temel ve Keskin, 2019a), Zea mays'da \%115.0 ile \%170.0 (Akdeniz ve ark., 2017), Sorghum sp'de 81.82 ile 120.16 (Temel ve ark., 2017), Medicago sativa'da 118.8 (Yavuz, 2005), olarak belirlenmiştir. Birçok yem bitkisi tür ve çeşitleri ile kıyaslandığında Amarant bitkisinde tespit edilen NYD değerinin yüksekliği Amarant bitkisinin yapraklarının büyük ve bol miktarda olmasından kaynaklandığı tahmin edilmektedir.

Çizelge 12. Yıl, yetiştirme şekli ve Amarant çeşitlerine göre saman NYD değeri.

Table 12. According to year, cultivation conditions (dry/irrigation) and Amarant varieties, straw RFV amount.

\begin{tabular}{|c|c|c|c|c|c|}
\hline \multirow[b]{2}{*}{ Yillar } & \multirow[b]{2}{*}{ Yetiştirme şekli } & \multicolumn{3}{|c|}{ Çeşitler } & \multirow[b]{2}{*}{ Yוl ort. } \\
\hline & & Helios & Sterk & Ultra & \\
\hline 2017 & $\begin{array}{l}\text { Kuru } \\
\text { Sulu } \\
\end{array}$ & $\begin{array}{l}134.8 b^{*} \\
99.8 d\end{array}$ & $\begin{array}{l}148.4 \mathrm{a} \\
93.7 \mathrm{de}\end{array}$ & $\begin{array}{l}97.3 \mathrm{~d} \\
89.5 \mathrm{e} \\
\end{array}$ & 110.5 \\
\hline 2018 & $\begin{array}{l}\text { Kuru } \\
\text { Sulu }\end{array}$ & $\begin{array}{l}150.5 \mathrm{a} \\
111.2 \mathrm{c} \\
\end{array}$ & $\begin{array}{l}153.7 \mathrm{a} \\
106.5 \mathrm{c} \\
\end{array}$ & $\begin{array}{l}74.4 \mathrm{f} \\
72.3 \mathrm{f}\end{array}$ & 111.4 \\
\hline Çeşit ort. & & $124.1 \mathrm{a}$ & $125.6 \mathrm{a}$ & $83.4 \mathrm{~b}$ & \\
\hline Yetiştirme şekli ort. & & Kuru: 12 & & Sulu: & \\
\hline
\end{tabular}

*Aynı harflerle gösterilen değerler arasındaki fark istatistiksel olarak önemli değildir.

\section{SONUÇ}

Araştırmanın ikinci yılında (2018), birinci yıla (2017) ve uzun yıllar ortalamasına göre sıcaklık, yağış ve nispi nem miktarının fazla gerçekleşmesi samanın HP, ADF ve KMT oranlarının yüksek çıkmasına neden olmuştur. Sulu şartlarda yetiştirilen Amarant çeşitlerinin samanlarının HP, NDF ve ADF içerikleri, kuru şartlarda yetiştirilen amarant çeşitlerinde ise KMS, KMT, SE, ME ve NYD içerikleri daha yüksek bulunmuştur. Helios çeşidinin samanlarındaki HP, $\mathrm{KMS}, \mathrm{SE}, \mathrm{ME}$, içerikleri diğer çeşitlere göre daha yüksek tespit edilmiştir. Tohum HP içeriğinde ise en yüksek değerler Ultra çeşidinde belirlenmiştir. NYD değeri yönünden Helios ve Sterk çeşitlerinde benzer sonuçlar alınmıştır. Aynı zamanda Helios çeşidinin ADF miktarı da düşük olmuştur.

Araştırma sonuçlarına göre, Helios çeşidinin tercih edilmesi elde edilecek tohum ve samanın daha kaliteli olmasını sağlayacaktır. Helios çeşidinin samanında HP, KMS, SE, ME, NYD değerinin yüksek olduğu, NDF ve ADF içeriğinin düşük olduğu görülmüş olup, belirtilen özellikler sulu ve kuru şartlarda da benzer özelliklere sahip olmuştur. 
Keskin ve ark., Sulu ve Kuru Koşullarda Yem Üretim Amacıyla Yetiştirilen Bazı Amarant Çeşitlerinin Tohum ve Saman Kalite Özelliklerinin Belirlenmesi

Ham protein, Kurak şartlarda amarant yetiştirilmesi durumunda yemin kalite özelliklerinde artışlar olacağı, diğer taraftan bitkinin sulu şartlarda yetiştirilmesi durumda da yem kalite özelliklerinde düşüşlerin olacağı sonucuna varılmıştır.

\section{ÇIKAR ÇATIŞMASI}

Yazarlar herhangi bir çıkar çatışması olmadığını beyan ederler.

\section{YAZAR KATKISI}

Yazarlar makaleye eşit oranda katkı sağlamışlardır.

\section{KAYNAKLAR}

Akdeniz, H., Temel, S., Keskin, B., \& Hosaflıoğlu, I. (2017). Compositons and Feeding Values of Silage Corn (Zea mays L.) varieties Grown as the Second Crop. VIII. International Scientific Agriculture Symposium, Jahorina.

Akyıldız, A. R. (1984). Yemler Bilgisi ve Laboratuar Kılavuzu. Ankara Üniversitesi Ziraat Fakültesi, Yayın No: 895, Ankara.

Alegbejo, J. O. (2013). Nutritional Value and Utilization of Amaranthus (Amaranthus spp.) - A Review. Bayero Journal of Pure and Applied Sciences, 6(1), 136-143.

Anonim. (2020). Amaranth - growing from seed when planted. Amaranth planting and care in the open field seed reproduction. https://dd-restaurant.ru/en/cabbage/amarant-vyrashchivanie-iz-semyan-kogda-sazhat-amarant-posadka-i-uhod-votkrytom/. Erişim tarihi: 28 Şubat 2020.

AOAC. (1997). Official Methods of Analysis. 16th ed. Association of Official Analytical Chemists AOAC Intl., Gaithersburg, MD.

Arendt, E. K., \& Zannini, E. (2013). Cereal Grains for the Food and Beverage Industries. Woodhead Publishing Series in Food Sciences, Technology and Nutrition, Philadelphia, USA.

Aufhammer, W., Kübler, E., \& Lee, J. H. (1999). Grain quality of the pseudocereals buckwheat (Fagopyrum esculentum Moench), quinoa (Chenopodium quinoa Willd.) and amaranth (Amaranthus hypochondriacus L. $\times$ A.hybridus L.) in relation to growing conditions. Die Bodenkultur, 50(1), 11-24.

Berghofer, E., \& Schoenlechner, R. (2002). Grain Amaranth. In Belton P, Taylor J: Pseudocereals and Less Common Cereals: Grain Properties and Utilization Potential. Springer-Verlag.

Betschart, A. A., Irving, D. W., Shepherd, A. D., \& Saunders, R. M. (1981). Amaranthus cruentus: milling characteristics, distribution of nutrients within seed components, and the effects of temperature on nutritional quality. Journal of Food Science, 46, 1181-1187.

Bressani, R. (1989). The proteins of grain amaranth. Food Review International, 5,13-38.

Caselato-Sousa, V. M., \&, Amaya-Farfàn, J. (2012). State of knowledge on amaranth grain: a comprehensive review. Journal of Food Science, 77(4), R93-R104.

Cheeke, P. R., \& Bronson, J. (1980). Feeding trials with amaranthus grain, forage and leaf protein concentrates. Second Amaranth Conference, Rodale Press, Emmaus, PA.

Connor, J. K., Gartner, R. J. W., Runge, B. M., \& Amos, R. N. (1980). Amaranthus edulis: an ancient food source re-examined. Australian Journal of Experimental Agriculture and Animal Husbandry, 20, 156-161.

Demir, U., \& Keskin, B. (2016). Sakız Geveni (Astragallus gummifer L.)'nin Yıllık Besin İçeriğinde Meydana Gelen Değişimlerin Belirlenmesi. Iğdır Üniversitesi Fen Bilimleri Enstitüsü Dergisi, 6(4),121-125.

Ergun, M., Özbay, N., Osmanoğlu, A., \& Çalkır, A. (2014). Sebze ve Tahıl Olarak Amarant (Amaranthus spp) Bitkisi. Iğdır Üniversitesi Fen Bilimleri Dergisi, 4(3), 21-28.

Fonnesbeck, P. V., Clark, D. H., Garret, W. N., \& Speth, C. F. (1984). Predicting energy utilization from alfalfa hay from the Western Region. Proceeding of American Society of Animal Sciences (Western Section), 35, 305-308.

Gimplinger, D. M., Dobos, G., Schönlechner, R., \& Kaul, H. P. (2007). Yield and quality of grain amaranth (Amaranthus sp.) in Eastern Austria. Plant, Soil and Environmental, 53(3), 105-112.

Goptsiy, T., Voroncov, N., Popov, V., Zhyravel, D., \& Gromenko, S. (2008). Grain Varieties of Amaranth Developed by Selection at Kharkiv National Agrarian University and the Perspectives of Their Use. In Amaranth-Plant of the Future: 5th International Symposium of the European Amaranth Association, Nitra, Slovak Republic. 
Keskin ve ark., Sulu ve Kuru Koşullarda Yem Üretim Amacıyla Yetiştirilen Bazı Amarant Çeşitlerinin Tohum ve Saman Kalite Özelliklerinin Belirlenmesi

Grubbens, G. J. H., \& van Sloten, D. H. (1981). Genetic Resources of Amaranths - a Global plan of Action. Rome: IBPGR.

Güngör, T., Başalan, M., \& Aydoğan, I. (2008). Kırıkkale yöresinde üretilen bazı kaba yemlerde besin madde miktarları ve metabolize olabilir enerji düzeylerinin belirlenmesi. Ankara Üniversitesi Veteriner Fakültesi Dergisi, 55, 111-115.

Hayıt, F., \& Gül, H. (2017). Çölyak ve çölyak hastaları için üretilen ekmeklerin kalite özellikleri. Iğdır Üniversitesi Fen Bilimleri Enstitüsü Dergisi, 7(1), 163-169

Jafari, H.R., Karimi, S., \& Alavipoor, F. S. (2018). Enviromental Planning and Management. In: Hesami M, Joneidabad MR, Kafi M, The Potential for the Use of Mutant Ornamental Plants for Reclamation of Arid Lands. Cambridge Scholars Publishing.

Jamriska, P. (1996). Vplyv odrod na urodu semena laskavca (Amaranthus sp.). [The influence of the variety on seed yield of amaranth (Amaranthus sp.)]. Rostlinna vyroba, 42(3), 109-114.

Johnson, B. L., \& Henderson, T. L. (2002). Water Use Patterns of Grain Amaranth in the Nrthern Great Plains. Agronomy Journal, 94(6), 1437-1443.

Kacar, B. (1972). Bitki ve toprağın kimyasal analizleri. Ankara Üniversitesi Ziraat Fakültesi Yayın No: 453, Ankara.

Karabulut, A., \& Canbolat, Ö. (2005). Yem Değerlendirme ve Analiz Yöntemleri. Uludağ Üniversitesi Ziraat Fakültesi Yayınları, Yayın No: 2.05.048.0424, Bursa.

Karakuş, B., \& Keskin, B. (2018). Devekıran (Atraphaxis spinosa I.) Çalısının Büyüme Sürecinde Besin İçeriğinin Değişimi Üzerine Bir Araştırma. Uluslararası Tarım ve Yaban Hayatı Bilimleri Dergisi, 4(1), 39 - 44.

Keskin, B., Akdeniz, H., Temel, S., \& Eren, B. (2018). Farklı Tane Mısır (Zea mays L.) Çeşitlerinin Besleme Değerlerinin Belirlenmesi. Atatürk Üniversitesi Ziraat Fakültesi Dergisi, 49(1), 15-19.

Keskin, B., \& Önkür, H. (2019). Kinoa (Chenopodium quinoa Willd.)'nın Tohum ve Saplarındaki Bazı Yem Kalite Özelliklerine Sıra Arası ve Sıra Üzeri Mesafelerinin Etkileri. Umteb 6. Uluslararası Mesleki ve Teknik Bilimler Kongresi, Iğdır Üniversitesi, Iğdır, Türkiye.

Khalil, J. K., Sawaya, W.N., \& Hyder, S. Z. (1986). Nutrient composition of Atriplex leaves grown in Saudi Arabia. Journal of Range Management, 39, 104-107.

Kır, A. E. (2016). Iğdır ekolojik koşullarında farklı Kinoa (Chenopodium quinoa Willd.) çeşit ve populasyonlarının tohum verimi ve bazı özelliklerinin belirlenmesi. Yüksek Lisans Tezi. Iğdır Üniversitesi Fen Bilimleri Enstitüsü, Iğdır.

Kır, A. E., \& Temel, S. (2016). Iğdır ovası kuru koşullarında farklı kinoa (Chenopodium quinoa Willd.) çeşit ve populasyonlarının tohum verimi ile bazı tarımsal özelliklerinin belirlenmesi. Iğdır Üniversitesi Fen Bilimleri Enstitüsü Dergisi, 6(4), $145-154$.

Kır, A. E., \& Temel, S. (2017). Sulu koşullarda farklı kinoa (Chenopodium quinoa Willd.) genotiplerinin tohum verimi ile bazı tarımsal özelliklerinin belirlenmesi. Iğdır Üniversitesi Fen Bilimleri Enstitüsü Dergisi, 7(1), 353-361.

Kutlu, H. R., Görgülü, M., \& Çelik, L. B. (2005). Genel Hayvan Besleme Ders Notu. Çukurova Üniversitesi Ziraat Fakültesi Zootekni Bölümü Yemler ve Hayvan Besleme Anabilim Dalı, Adana.

Kutlu, H. R., \& Özen, N. (2009). Hayvan Beslemede Son Gelişmeler. VI. Ulusal Zootekni Bilim Kongresi, Erzurum.

Laovoravit, N., Kratzer, F. H., \& Becker, R. 1986. The Nutritional Value of Amaranth for Feeding Chickens. Poultry Science, 65, 1365-1370.

Lee, C. (2011). Grain Amaranth. University of Kentucky, College of Agriculture, Cooperative Extension Service, http://www.uky.edu/Ag/CCD/introsheets/amaranth.pdf. Access date: August 15, 2020.

Lehman, J. (1989). Proteins of grain amaranth. Legacy 2, 3-6.

Maneerat, W., Prasanpanich, S., Tumwasorn, S., Laudadio, V., \& Tufarelli, V. (2015). Evaluating agro-industrial by-products as dietary roughage source on growth performance of fattening steers. Saudi Journal of Biological Sciences, 22, 580-584.

Martirosyan, D. M. (2005). Functional Foods for Cardiovascular Diseases. D and A Inc. In: Miroshnichenlo, L. A., Zharkova, U. M., Kulakova, S. N., Kadirov, C. V., Eprintsev, A. T., Kalinicheva, M. V., Amaranth: A Few Aspects of Cultivation, Processing, Studies of Pharmaceutıcal Properties.

McDonald, P., Edwards, R.A., Greenhalgh, J. F. D., Morgan, C. A., Sinclair, L. A., \& Wilkinson, R. G. (2011). Animal Nutrition. Seventh Edition. Publisher: Pearson.

MGM. (2019). T.C. Tarım ve Orman Bakanlığı Meteoroloji Genel Müdürlüğü, Ankara.

Nurfeta, A., Tolera, A., Eik, L. O., \& Sundstøl, F. (2009). Feeding value of enset (Ensete ventricosum), Desmodium intortum hay and untreated or urea and calcium oxide treated wheat straw for sheep. Journal of Animal Physiology and Animal Nutrition, 93(1), 94-104. 
Keskin ve ark., Sulu ve Kuru Koşullarda Yem Üretim Amacıyla Yetiştirilen Bazı Amarant Çeşitlerinin Tohum ve Saman Kalite Özelliklerinin Belirlenmesi

Oddy, V. H., Robards, G. E., \& Low, S. G. (1983). Prediction of in vivo dry matter digestibility from the fiber nitrogen content of a feed. Feed Information and Animal Production. Common wealth Agricultural Bureau, Farnham Royal, UK.

Olaniyi, J. O., Adelasoye, K. A., \& Jegede, C. O. (2008). Influence of nitrogen fertilizer on the growth, yield and quality of grain amaranth varieties. World Journal of Agricultural Science, 4(4), 506-513.

Öncel, I., Üstün, S., \& Keleş, Y. (2004). Bitki Fizyolojisi Laboratuvar Kılavuzu. A.Ü.F.F. Döner Sermaye İşletmesi Yayınları No: 48, Ankara.

Özaslan, C., \& Kendal, E. (2014). Lice Domatesi Üretim Alanlarındaki Yabancı Otların Belirlenmesi. Iğdır Üniversitesi Fen Bilimleri Enstitüsü Dergisi, 4(3), 29-34.

Pospisil, A., Pospisil, M., Varga, B., \& Svecnjak, Z. (2006). Grain yield and protein concentration of two amaranth species (Amaranthus spp.) as influenced by the nitrogen fertilization. European Journal of Agronomy, 25, 250-253.

Pospisil, A., Pospisil, M., Macesic, D., \& Svecnjak, Z. (2009). Yield and Quality of Forage Sorghum and Different Amaranth Species (Amaranthus spp.) Biomass. Agriculturae Conspectus Scientificus, 74(2), 85-89.

Pospisil, A., Pospisil, M., Poljak, M., \& Jukic, Z. (2008). Influence of nitrogen fertilization on the chemical composition of amaranth (Amaranthus spp.) seed. Cereal research communications, 36(Suppl), 1227-1230.

Rastogi, A., \& Shukla, S. (2013). Amaranth: A new millennium crop of nutraceutical values. Critical Reviews in Food Science and Nutrition, 53, 109-125.

Ravindran, V., Hood, R.L., Gill, R. J., Kneale, C. R., \& Bryden, W. L. (1996). Nutritional evaluation of grain arnaranth (Amaranthus hypochondriacus in broiler diets. Animal Feed Science Technology, 63, 323-331.

Robinson, R. G. (1986). Amaranth, Quinoa, Ragi, Tef and Niger: Tiny seeds of Ancient History and Modern Interest. Minnesota Agric. Exp. Stn. Bull, AD-SB-2949.

Sauer, J. D. (1976). Grain amaranths, Amaranthus spp. (Amaranthaceae). Evolution of crop plants, Longman, London, United Kingdom.

Selçuk, H. (2011). Çukurova koşullarında dane Amarant'ın (Amaranthus spp.) kuraklığa dayanma yönünden incelenmesi. Yüksek Lisans Tezi, Çukurova Üniversitesi Fen Bilimleri Enstitüsü, Adana.

Sheaffer, C. C., Peterson, M. A., Mccalin, M., Volene, J. J., Cherney, J. H., Johnson, K. D., Woodward, W. T., \& Viands, D. R. (1995). Acid detergent fiber, neutral detergent fiber concentration and relative feed value. North American Alfalfa Improvement Conference, Minneapolis.

Stahlknecht, G. F., \& Schulz-Schaeffer, J. R. (1993). Amaranth Rediscovered. New crops, Wiley, New York.

Svirskis, A. (2003). Investigation of Amaranth Cultivcation and Utilisation in Lithuania. Agronomy Research, 1(2), $253-264$.

Şehu, A., Sakine, Y., \& Önol, A. G. (1996). Bazı buğdaygil samanlarının in vivo sindirilme dereceleri ve rumende parçalanma özellikleri. Ankara Universitesi Veteriner Fakültesi Dergisi, 43, 469-477.

Tan, M., \& Temel, S. (2012). Alternatif Yem bitkileri. Atatürk Üniversitesi Ziraat Fakültesi Ders yayınları. Yayın No: 246.

Temel, I., \& Keskin, B. (2019a). Farklı sıra arası ve sıra üzeri mesafelerinin kinoa (Chenopodium quinoa Willd.)'nın besin içeriğine etkisi. Uluslararası Tarım ve Yaban Hayatı Bilimleri Dergisi, 5(1),110-116.

Temel, S., \& Keskin, B. (2019b). Annual evaluation of nutritıonal values of salsola ruthenica evaluated as a potential feed source in ariid-pasture areas. Fresenius Environmental Bulletin, 28(10), 7137-7144.

Temel, S., Keskin, B., Akdeniz, H., \& Eren, B. (2017). Nutrient Content of Some Silage Sorghum Varieties Grown as Second Crop Under Igdir Ecological Condition. VIII. International Scientific Agriculture Symposium, Jahorina.

Temel, S., Keskin, B., Yıldız, V., \& Kır, A. E. (2015). Iğdır ovası taban koşullarında adi fiğ (Vicia sativa L.) çeşitlerinin kuru ot verimi ve kalite özelliklerinin incelenmesi. Iğdır Üniversitesi Fen Bilimleri Enstitüsü Dergisi, 5(3), 67-76.

Uusikua, N. P., Oelofsea, A., Duodub, K. G., Besterc, M. J., \& Faberd, M. (2010). Nutritional value of leafy vegetables of subSaharan Africa and their potential contribution to human health: A review, In: Journal of Food Composition and Analysis, 23, 499-509.

Van Soest, P. J., Robertson, J. B., \& Lewis, B. A. (1991). Methods for diatery fiber, neutral detergent fiber and nonstarch polysaccharides in relation to animal nutrition. Journal of Dairy Science, 74, 3583-3597.

Venskutonis, P. R., \& Kraujalis, P. (2013). Nutritional components of amaranth seeds and vegetables: a review on composition, properties, and uses. Comprehensive Reviews in Food Science and Food Safety, 12, 381-412.

Yarnia, M., İkincikarakaya, S. Ü., Rezaei, F., \& Khawar, K. M. (2011). Çavdar Kalıntılarının, Horoz İbiğinin (Amaranthus retroflexus L.) Toprakta Bulunan Tohum Miktarı ve Bitki Gelişimi Üzerine Etkisi. Iğdır Üniversitesi Fen Bilimleri Enstitüsü Dergisi, 1(2), 91-96. 
Keskin ve ark., Sulu ve Kuru Koşullarda Yem Üretim Amacıyla Yetiştirilen Bazı Amarant Çeşitlerinin Tohum ve Saman Kalite Özelliklerinin Belirlenmesi

Yaroshko, O. M., \& Kuchuk, M. V. (2018). Agrobacterium - caused transformation of cultivars Amaranthus caudatus L. and A.hybrids of A. caudatus L. x A. paniculatus L. International Journal of Secondary Metabolite, 5(4), 312-318.

Yavuz, M. (2005). Bazı ruminant yemlerinin nispi yem değeri ve in vitro sindirim değerlerinin belirlenmesi. Tokat Gaziosmanpaşa Üniversitesi Ziraat Fakültesi Dergisi, 22(1), 97-101. 